\title{
A screening technique to evaluate pigeonpea for resistance to Rotylenchulus reniformis*
}

\author{
By S. B. SHARMA and P. ASHOKK UMAR \\ Legumes Program, International Crops Research Institute for the Semi-Arid Tropics \\ (ICRISAT), Patancheru P.O., Andhra Pradesh 502 324, India
}

(Accepted 17 May 1991)

\begin{abstract}
Summary
Rotylenchulus reniformis is one of the most important nematode pests of pigeonpea. A simple greenhouse technique has been developed to aid evaluation of pigeonpea genotypes for resistance to $R$. reniformis. In greenhouse pot experiments, eggsacs of $R$. reniformis in pigeonpea (cv. ICPL 87) roots were counted by eye and with the aid of a stereoscopic microscope at 15,30 and 45 days after seedling emergence in soils infested with various numbers of vermiform $\boldsymbol{R}$. reniformis. Seedlings were rated for the number of eggsacs per root system on a one (no eggsacs) to nine (more than 50 eggsacs) scale. Eggsac ratings were more uniform when roots were evaluated at $30-45$ days than at 15 days and an inoculum of 15 to 30 individuals $/ \mathrm{cm}^{3}$ soil also helped reduce variability. Eggsacs were not easily visible without the aid of a stereoscopic microscope. Of the 14 stains tested, exposure of nematode-infected roots to $0.25 \%$ trypan blue for three min was effective in staining the eggsacs blue without staining the roots. Using the stain, the assessment of infestation by $R$. reniformis was equally accurate with or without the aid of a stereoscopic microscope. Exposure of eggsacs to trypan blue enhanced the emergence of juveniles from the eggsacs.
\end{abstract}

Key words: Cajanus cajan, host plant resistance, pigeonpea, reniform nematode, Rotylenchulus reniformis

\section{Introduction}

The reniform nematode, Rotylenchulus reniformis Linford and Oliveira, is one of the important nematode pests of pigeonpea (Cajanus cajan (L.) Millsp.) in Fiji, India, Jamaica and Trinidad (Sharma \& McDonald, 1990). Infestation by this nematode results in poor crop growth and heavily infected plants have yellowish leaves and reduced biomass (Sharma \& Nene, 1988). The nematode has a very wide host range, rendering crop rotation an ineffective method of control, and the use of nematicides is uneconomical. Therefore, growing nematode-resistant cultivars of pigeonpea is the most desirable management practice.

Nematode attack does not produce any characteristic above ground symptoms useful in distinguishing susceptible from resistant genotypes. Numbers of nematode females, eggsacs and eggs on a plant are good indicators of the disease stress imposed, and efforts have been made to use such data to screen pigeonpea genotypes for resistance (Chavda, Patel \& Patel, 1988; Patel, Chavda, Patel \& Patel, 1987; Thakar \& Yadav, 1987). Current screening procedures involve inoculation of vermiform stages of $R$. reniformis onto the roots of host seedlings and counting under a stereoscopic microscope the numbers of females and/or eggsacs that develop on the roots. This is usually done after staining the root systems in hot

- Submitted as ICRISAT Journal Article No. 1155 by the International Crops Research Institute for the Semi-Arid Tropics (ICRISAT), Patancheru P.O., Andhra Pradesh 502 324, India

(C) 1991 Association of Applied Biologists 
acid fuchsin lactophenol. This procedure is slow, and impractical for screening large numbers of genotypes in a breeding programme.

The objective of this study was to develop a simple, and reliable greenhouse screening procedure based on the number of eggsacs on the roots. We evaluated 14 stains (dyes) for their efficacy to facilitate counting of eggsacs on the roots without the aid of a microscope.

\section{Materials and Methods}

\section{Nematode inoculum}

Rotylenchulus reniformis was collected in December 1986 from a pigeonpea field on an Alfisol (red soil) at the research farm $\left(17^{\circ} \mathrm{N} 78^{\circ} \mathrm{E} 545 \mathrm{~m}\right)$ of the International Crops Research Institute for the Semi-Arid Tropics (ICRISAT), Andhra Pradesh, India. The nematode was reared on susceptible pigeonpea cultivars (ICPL 87 and ICP 2376) in $20 \mathrm{~cm}$ diameter plastic pots containing autoclaved river bed sand plus farm yard manure plus Alfisol $(2: 1: 1$, by volume) in a greenhouse maintained at approximately $30^{\circ} \mathrm{C}$. The plants were harvested after three months and the infested pot soil was mixed with autoclaved river bed sand and Alfisol ( $1: 1$, by volume). This soil mix was used to fill thirty more pots. Five seeds of pigeonpea cultivar (ICPL 87) were sown in each pot to increase the nematode inoculum further.

The nematode-infested soil thus produced was bulked, thoroughly mixed to distribute the nematode population uniformly, and divided into eight parts. The first part was maintained as a control, and the other seven parts were mixed with different quantities of autoclaved sand and Alfisol $(1: 1)$ to obtain a total of eight infestation levels. The soil samples were incubated at $28^{\circ} \mathrm{C}$ for one week to facilitate emergence of juveniles from the eggs. Population densities of $R$. reniformis at each infestation level were estimated in $100 \mathrm{~cm}^{3}$ soil samples.

Juveniles, males and immature slender females of $R$. reniformis were extracted from the $100 \mathrm{~cm}^{3}$ soil samples by suspending them in water and pouring the suspensions through nested sieves ( 850 and $38 \mu \mathrm{m}$ pore sizes). The residues from the $38 \mu \mathrm{m}$ pore sieves were placed on double layers of Kimwipes tissue papers supported on wire mesh in $9 \mathrm{~cm}$ diameter Petri dishes containing sufficient water to cover the residue. The Petri dishes were incubated at $25 \pm 2{ }^{\circ} \mathrm{C}$ for $48 \mathrm{~h}$ to allow the nematodes to pass into the water; the nematodes were then counted. After counting, soils containing inoculum densities of $0.4,0.9,1.3,6.0,15,20,25$ and 30 individuals per $\mathrm{cm}^{3}$ soil were used to fill $12.5 \mathrm{~cm}$ diameter plastic pots. Holes in the bottoms of these pots were closed with cotton wool plugs before adding $1000 \mathrm{~cm}^{3}$ soil to each pot.

\section{Screening procedure}

Five seeds of pigeonpea cv. ICPL 87 were sown in each of the pots containing nematodeinfested soils. There were six pots for each of the eight infestation levels. At 15, 30 and 45 days after seedling emergence, the roots in two pots from each infestation level were carefully washed free of soil and the eggsacs were counted under a stereoscopic microscope. Each root system was separately rated on a 1 to 9 index where $1=$ no eggsacs, $2=1-5,3=6-10$, $4=11-15,5=16-20,6=21-30,7=31-40,8=41-50$ and $9=$ more than 50 eggsacs. The date were statistically analysed for variance and means and standard errors of the means were determined. Coefficients of variation were calculated, and t-tests were used to compare the means.

Influence of staining on the visibility of $\mathbf{R}$. reniformis eggsacs

Fourteen stains (see Table 3 ) were evaluated. Infected 30 day old seedlings (cv. ICPL 87) were gently removed from the pots and their roots were dipped for $10 \mathrm{~min}$ in one of 14 stains. 
The roots were then carefully washed with tap water to remove excess stain before spreading them out in water in Petri dishes. The colours of eggsacs and of roots were recorded. Numbers of eggsacs per root system were counted with the unaided eye and with the aid of a stereoscopic microscope. An index of differentiation based on the contrast of eggsacs to root colour was used to evaluate the usefulness of each stain on a 1 (excellent) to 5 (poor) scale. Efficiency of a stain was calculated as a percentage of eggsacs counted with the unaided eye relative to the number of eggsacs counted with the help of a stereoscopic microscope.

Stains with differentiation indices of 1 to 3 were investigated further. Infected roots were exposed for 3,5 and $10 \mathrm{~min}$ to three concentrations $(0.25 \%, 0.5 \%$ or $1.0 \%)$ of stain, except for Giemsa's stain (where $10.0 \%, 5.0 \%$ and $2.5 \%$ were used) and for Coomassie brilliant blue (where $0.5 \%, 0.25 \%$ and $0.15 \%$ were used). The roots were rated for eggsacs on 1 to 9 scale by eye as well as with the help of a stereoscopic microscope.

\section{Effects of staining on emergence of juveniles of $\mathbf{R}$. reniformis from eggsacs}

Stained eggsacs from the lowest and highest concentrations of staining treatments were collected and incubated at $25 \pm 2{ }^{\circ} \mathrm{C}$ in water in $2.5 \mathrm{~cm}$ diameter Petri dishes. Numbers of emerged juveniles were counted after 2, 4 and 12 days; the emerged juveniles were removed after each counting and fresh water was added to the Petri dishes. After 12 days, the numbers of unhatched eggs and juveniles in the eggsacs were counted. Percentage emergence was calculated and the data were subjected to analysis of variance after arc-sin transformation of percentages.

\section{Drenching of pigeonpea rhizosphere with trypan blue}

Nematode infested soil with $15 \mathrm{~cm}$ diameter pots containing 30 day old seedlings of $\mathrm{cv}$. ICPL 87 were irrigated with $50 \mathrm{ml}$ of $1.0 \%, 0.75 \%, 0.5 \%$ or $0.4 \%$ trypan blue. Pots irrigated with $50 \mathrm{ml}$ of tap water were maintained as controls. Seedlings were removed gently from the pots 4,6 and $24 \mathrm{~h}$ after adding the stain to the rhizosphere. After gently washing the roots in tap water, the numbers of eggsacs on the roots of five plants for each treatment were counted directly or with the aid of a stereoscopic microscope. Efficiency of a treatment was calculated as previously described. The data were statistically analysed using analysis of variance.

\section{Screening of pigeonpea genotypes}

Twenty pigeonpea genotypes obtained from the Genetic Resources Unit of ICRISAT were evaluated for their reaction to $R$. reniformis using the technique of staining roots with trypan blue, and rating procedure described above.

\section{Results}

\section{Infestation levels of $\mathbf{R}$. reniformis and eggsac counts}

Eggsac production differed with the level of soil infestation and the age of seedling. Eggsac counts were lower except at the three lowest infestation levels $(P=0.05) 15$ days after seedling emergence than at 30 and 45 days (Table 1). Infestation levels of 15 or more $R$. reniformis per $\mathrm{cm}^{3}$ soil resulted in more $(P=0.05)$ eggsacs per root system than when 6.0 or fewer nematodes per $\mathrm{cm}^{3}$ were used. Infestation levels of 15 and more individuals per root system gave uniform eggsac indices while lower infestation levels resulted in variable indices (Table 2). Eggsac indices of 15 day old seedlings ranged between 2.0 and 8.3 and the coefficients of variation were high. Eggsac indices of 30 and 45 day old seedlings were less variable, particularly with inocula of 15 to $30 R$. reniformis individuals per $\mathrm{cm}^{3}$ soil. Many immature females without eggsacs were observed when roots of 15 day old seedlings were examined. 
Table 1. Numbers of eggsacs of $R$. reniformis on pigeonpea (ICPL 87) roots 15,30 and 45 days after seedling emergence in nematode infested soils

$\begin{array}{cccc}\begin{array}{c}R . \text { reniformis } \\ \text { infestation } \\ \text { level/cm }\end{array} & \begin{array}{c}\text { No. of eggsacs } \\ \text { after } 15 \text { days }\end{array} & \begin{array}{c}\text { No. of eggsacs } \\ \text { after } 30 \text { days }\end{array} & \begin{array}{c}\text { No. of eggsacs } \\ \text { after } 45 \text { days }\end{array} \\ 0.4 & 6.4 \pm 6.0^{\mathrm{c}+} & 13.2 \pm 5.7^{\mathrm{d}+*} & 29.5 \pm 7.4^{\mathrm{cd} *} \\ 0.9 & 6.8 \pm 6.0^{\mathrm{c}+} & 21.8 \pm 7.1^{\mathrm{cd}+} & 31.5 \pm 6.4^{\mathrm{cd}+} \\ 1.3 & 2.5 \pm 6.2^{\mathrm{c}+} & 10.2 \pm 7.1^{\mathrm{d}+*} & 22.3 \pm 6.4^{\mathrm{d} *} \\ 6.0 & 10.3 \pm 6.4^{\mathrm{c}+} & 35.6 \pm 6.2^{\mathrm{c}} & 41.9 \pm 6.4^{\mathrm{c} *} \\ 15.0 & 52.6 \pm 8.1^{\mathrm{b}+} & 137.5 \pm 10.4^{\mathrm{a} *} & 137.6 \pm 6.8^{\mathrm{a} *} \\ 20.0 & 37.1 \pm 8.5^{\mathrm{b}+} & 79.0 \pm 9.0^{\mathrm{b} *} & 130.4 \pm 9.7^{\mathrm{a}} \\ 25.0 & 49.0 \pm 9.7^{\mathrm{b}+} & 89.5 \pm 10.4^{\mathrm{b} *} & 85.0 \pm 9.0^{\mathrm{b} *} \\ 30.0 & 76.5 \pm 6.6^{\mathrm{a}+} & 90.6 \pm 7.7^{\mathrm{b} *} & 130.9 \pm 8.1^{\mathrm{a} *}\end{array}$

Figures followed by same symbol in the rows are not significantly different $(P=0.05)$. Figures followed by same letter in columns are not significantly different $(P=0.05)$.

Table 2. Eggsac indices of pigeonpea (ICPL 87) roots 15, 30 and 45 days after seedling emergence in soils infested with eight levels of $\mathbf{R}$. reniformis

$\begin{array}{cccc}\begin{array}{c}R . r e n i f o r m i s \\ \text { infestation } \\ \text { level/cm }{ }^{3} \text { soil }\end{array} & \begin{array}{c}\text { Time of evaluation } \\ \text { (days after } \\ \text { seedling emergence) }\end{array} & \begin{array}{c}\text { Average } \\ \text { eggsac } \\ \text { index } \pm \text { S.E. }\end{array} & \begin{array}{c}\text { Coefficie } \\ \text { of variation }\end{array} \\ 30 & 15 & 8.3 \pm 0.33 & 15.5 \\ 25 & 15 & 6.6 \pm 1.13 & 45.5 \\ 20 & 15 & 6.7 \pm 0.62 & 28.1 \\ 15 & 15 & 7.6 \pm 0.60 & 25.0 \\ 6 & 15 & 3.2 \pm 0.49 & 61.9 \\ 1.3 & 15 & 2.0 \pm 0.17 & 35.7 \\ 0.9 & 15 & 2.8 \pm 0.32 & 48.7 \\ 0.4 & 15 & 2.8 \pm 0.15 & 23.3 \\ 30 & 30 & 8.9 \pm 0.09 & 3.4 \\ 25 & 30 & 8.9 \pm 0.13 & 4.0 \\ 20 & 30 & 8.5 \pm 0.34 & 9.8 \\ 15 & 30 & 9.0 \pm 0.00 & 0.0 \\ 6 & 30 & 6.8 \pm 0.37 & 22.1 \\ 1.3 & 30 & 3.3 \pm 0.37 & 55.7 \\ 0.9 & 30 & 5.2 \pm 0.44 & 30.4 \\ 0.4 & 30 & 4.0 \pm 0.32 & 36.3 \\ 30 & 45 & 9.0 \pm 0.00 & 0.0 \\ 25 & 45 & 8.9 \pm 0.14 & 4.3 \\ 20 & 45 & 8.8 \pm 0.41 & 14.1 \\ 15 & 45 & 9.0 \pm 0.00 & 0.0 \\ 6 & 45 & 7.6 \pm 0.33 & 17.2 \\ 1.3 & 45 & 5.1 \pm 0.46 & 36.2 \\ 0.9 & 45 & 6.5 \pm 0.33 & 20.2 \\ 0.4 & 45 & 6.4 \pm 0.26 & 14.0\end{array}$

Eggsac index : $1=$ no eggsacs, $2=1-5,3=6-10,4=11-15,5=16-20,6=21-$ $30,7=31-40,8=41-50$ and $9=$ more than 50 eggsacs. 
Table 3. Efficacy of different stains in differentiating Rotylenchulus reniformis eggsacs from pigeonpea roots

\begin{tabular}{|c|c|c|c|c|c|c|c|}
\hline Stain & Source & $\begin{array}{c}\text { Concentration } \\
\text { used for staining } \\
(\%)\end{array}$ & $\begin{array}{l}\text { Colo } \\
\text { the }\end{array}$ & $\begin{array}{l}\text { ur of } \\
\text { roots }\end{array}$ & $\begin{array}{l}\text { Colo } \\
\text { the eg }\end{array}$ & $\begin{array}{l}\text { ur of } \\
g \text { sacs }\end{array}$ & $\begin{array}{c}\text { Index of } \\
\text { differentiation }\end{array}$ \\
\hline Aniline blue* & BDH, UK & 1.0 & $++t$ & Pink & $+t$ & Purple & 3 \\
\hline Azur II eosine* & Loba-Chemie, India & 1.0 & +++ & Blue & $+t+$ & Purple & 3 \\
\hline Brilliant blue $R^{*}$ & BDH, India & 1.0 & ++ & Violet & +++ & Violet & 3 \\
\hline Brilliant green & BDH, India & 1.0 & ++ & Green & +++ & Green & 3 \\
\hline $\begin{array}{l}\text { Coomassie } \\
\text { brilliant blue }\end{array}$ & Bio-Rad Lab, USA & 1.0 & - & & + & Violet & 3 \\
\hline Cotton blue & $\begin{array}{l}\text { Loba-Chemie } \\
\text { Indoaustranal Co. Ltd., } \\
\text { India }\end{array}$ & 1.0 & + & Blue & + & Blue & 5 \\
\hline Eosine & BDH, India & 1.0 & + & Blue & - & & 5 \\
\hline Giemsa's stain & $\begin{array}{l}\text { Nice New India Chemical, } \\
\text { India }\end{array}$ & 10.0 & + & Purple & ++ & Purple & 5 \\
\hline Haematoxylin* & Loba-Chemie, India & 1.0 & + & Brown & ++ & Brown & 3 \\
\hline Methylene blue & BDH, India & 1.0 & ++ & Blue & +++ & Blue & 3 \\
\hline Nigrosin & E. Merck, Germany & 1.0 & - & & - & & 5 \\
\hline Orange $\mathrm{G}$ & $\mathrm{BDH}$, India & 3.0 & - & & - & & 5 \\
\hline Phloxine B & Allied Chemicals, USA & 0.015 & + & Pink & - & & 3 \\
\hline Trypan blue & $\begin{array}{l}\text { Matheson, Coleman \& Bell } \\
\text { Manufacturing Chemists, } \\
\text { USA }\end{array}$ & 1.0 & - & & $+t+$ & Blue & 1 \\
\hline
\end{tabular}

Roots were stained for $10 \mathrm{~min}$.

- These were initially dissolved in $10 \mathrm{ml}$ of ethyl alcohol before making up the volume with water.

$t+=$ Light colour, $+t=$ moderate colour, $++t=$ deep colour, $-=$ no colour.

$\ddagger$ Index of differentiation (ability of a stain to facilitate visual counting of eggsacs on the roots : $1=$ excellent and $5=$ poor $)$.

\section{Influence of staining on the visibility of $\mathrm{R}$. reniformis eggsacs}

Ten stains coloured the eggsacs (Table 3). Azur II eosine, brilliant blue R, brilliant green, methylene blue and trypan blue resulted in marked staining of the eggsacs. Differentiation of eggsacs on the roots was excellent with the use of trypan blue and counting of eggsacs with the unaided eye was simple (Table 4). Although useful in differentiating the eggsacs from root tissues, the other stains were not as good as trypan blue at allowing reliable counts of eggsacs to be made with unaided eye (Table 5). Correlation coefficients of eggsac indices from unaided eye and microscope observations were positive and significant $(P=0.05)$ with $0.25 \%$ trypan blue after 3, 5 and 10 min staining of infected roots.

Emergence of $\mathbf{R}$. reniformis juveniles from stained eggsacs

Staining of eggsacs significantly $(P<0.01)$ increased the emergence of juveniles from the eggsacs. The two concentrations of stains tested $(1.0 \%$ and $0.25 \%)$ had similar effects on juvenile emergence from eggsacs. Exposure of eggsacs for $10 \mathrm{~min}$ significantly $(P=0.01)$ increased the mean emergence $(66.9 \%)$ of juveniles compared to exposure for $5 \mathrm{~min}(50.8 \%)$ and $3(44.1 \%)$ min. Mean emergence in haematoxylin $(64.8 \%)$, azur II eosin $(61.1 \%)$ and brilliant blue $\mathrm{R}(64.7 \%)$ was significantly grater $(P=0.05)$ than that in other stains except Coomassie blue (Table 5). In comparison with emergence in the control (no stain), an increase in emergence of juveniles from eggsacs placed in methylene blue, brilliant green, trypan blue and aniline blue was observed only at an exposure time of $10 \mathrm{~min}$. 
Table 4. Comparison of three concentrations of nine stains for their efficiency to stain $\mathrm{R}$. reniformis eggsacs

Time of

exposure

of roots

Stain to the

dilution* stain

$(\%) \quad(\min )$

Methylene Giemsa's Trypan Haema-

Coomassie

$0.25 \quad 10$

$0.25 \quad 5$

$0.25 \quad 3$

blue stain blue toxylin

brilliant

$\begin{array}{llll}31.3 & 46.25 & 84.1 & 25.1\end{array}$

$13.4 \quad 48.8$

83.4

25.1
65.2

blue

Azur II Brilliant Brilliant Aniline

$\begin{array}{lll}38.2 & 14.8 & 79.0\end{array}$

31.4

31.4

50.5

19.9

38.1

eosin blue $\mathrm{R}$ blue blue

25.3

34.8

74.0

62.0

40.6

$\begin{array}{llll}56.1 & 63.9 & 40.9 & 31.9\end{array}$

$\begin{array}{llll}42.5 & 13.5 & 46.6 & 53.0\end{array}$

$\begin{array}{llll}22.6 & 34.1 & 79.8 & 37.0\end{array}$

$12.6 \quad 35.2$

80.6

28.0

18.9

55.6

$\begin{array}{llll}25.1 & 31.2 & 37.3 & 11.3\end{array}$

$\begin{array}{llll}38.7 & 28.6 & 33.3 & 26.4\end{array}$

$26.4 \quad 43.8$

$84.8 \quad 38.8$

37.7

21.4

$29.0 \quad 19.4$

$24.8 \quad 27.2$

85.0

32.2

36.0

19.3

21.5

11.7

18.7

39.3

78.3

34.2

35.4

30.7

33.1

26.3

32.7

30.6

38.2

25.2

16.7

42.5

32.7

L.S.D. $(P=0.05)=17.72$.

* Stain dilutions were $10.0 \%, 5.0 \%$ and $2.5 \%$ for Giemsa's stain and $0.5 \%, 0.25 \%$, and $0.15 \%$ for Coomassie brilliant blue.

Efficiency of a stain $=$ the number of eggsacs counted with unaided eye expressed as a percentage of the number of eggsacs counted with aid of a stereoscopic microscope.

Table 5. Effect of nine selected stains on emergence of $\mathrm{R}$. reniformis juveniles from eggsacs

\begin{tabular}{|c|c|c|c|c|}
\hline & \multicolumn{3}{|c|}{$\begin{array}{l}\text { Exposure time of eggsacs in } \\
\text { different stains (in min) }\end{array}$} & \multirow[b]{2}{*}{ Mean } \\
\hline & 10 & 5 & 3 & \\
\hline Methylene blue & 74.8 & 41.9 & 27.8 & 48.2 \\
\hline Giemsa's stain & 53.4 & 53.2 & 27.0 & 44.5 \\
\hline Trypan blue & 74.3 & 24.2 & 34.6 & 44.4 \\
\hline Haematoxylin & 83.8 & 51.8 & 58.9 & 64.8 \\
\hline Coomassie brilliant blue & 66.0 & 65.9 & 50.1 & 60.7 \\
\hline Azur II eosin & 73.5 & 64.8 & 45.0 & 61.1 \\
\hline Brilliant green & 64.3 & 45.7 & 54.9 & 55.0 \\
\hline Brilliant blue $\mathbf{R}$ & 76.3 & 64.4 & 53.3 & 64.7 \\
\hline Aniline blue & 64.6 & 50.3 & 51.1 & 55.4 \\
\hline Control & 38.1 & 38.1 & 38.1 & 38.1 \\
\hline L.S.D. $(P=0.05)$ & & & 19.92 & 5.36 \\
\hline Mean & 66.9 & 50.0 & $\begin{array}{l}44.1 \\
12.55\end{array}$ & \\
\hline
\end{tabular}

N.B. For Giemsa's stain $10 \%$ and $2.5 \%$, for Coomassie brilliant blue $0.5 \%$ and $0.15 \%$, and for other stains $1.0 \%$ and $0.25 \%$ concentrations were used. Emergence of juveniles in the two tested concentrations did not differ $(P=0.05)$. Average emergence presented in the table.

\section{Drenching of rhizosphere soil with trypan blue}

Drenching soil with $1.0 \%, 0.75 \%, 0.5 \%$ and $0.4 \%$ trypan blue for 4,6 and $24 \mathrm{~h}$ stained the eggsacs and facilitated counting (Table 6). Ratings of eggsacs on roots by the unaided eye and using a stereoscopic microscope did not differ significantly $(P=0.05)$. Rating of $R$. reniformis eggsacs on the roots of control plants (no stain treatment) was 3 with the unaided eye 
Table 6. Efficiency of drenching $\mathrm{R}$. reniformis infested rhizosphere soil with trypan blue on eggsac ratings on pigeonpea (ICPL 87) roots

$\begin{array}{llcc}\begin{array}{c}\text { Trypan } \\ \text { blue }(\%)\end{array} & \overbrace{4 \mathrm{~h}} \text { Efficiency* of drenching rhizosphere soil for } \\ 1.0 & 72.6 \pm 4.57^{+* \mathrm{a}} & 73.1 \pm 4.08^{* \mathrm{a}} & 61.7 \pm 3.23^{+\mathrm{a}} \\ 0.75 & 63.0 \pm 3.73^{+\mathrm{a}} & 70.2 \pm 4.57^{+\mathrm{ab}} & 64.4 \pm 3.45^{+\mathrm{a}} \\ 0.5 & 53.7 \pm 3.73^{+\mathrm{h}} & 68.9 \pm 3.73^{* \mathrm{ab}} & 60.4 \pm 5.27^{+* \mathrm{a}} \\ 0.4 & 41.8 \pm 3.73^{+\mathrm{c}} & 59.1 \pm 3.45^{* \mathrm{~b}} & 45.9 \pm 4.08^{+\mathrm{b}} \\ 0.0 & 20.7 \pm 3.73^{+\mathrm{d}} & 20.7 \pm 3.73^{+\mathrm{c}} & 20.7 \pm 3.73^{+\mathrm{c}}\end{array}$

- Number of eggsacs counts with unaided eye divided by eggsacs counts with aid of a stereoscopic microscope $\times 100$.

Mean $\pm S . E$. in columns followed by the same letter are not significantly $(P=0.05)$ different and mean \pm S.E. in rows followed by the same symbol are not significantly different $(P=0.05)$.

and 7 when the roots were evaluated under a stereoscopic microscope. Use of $1.0 \%$ and $0.75 \%$ trypan blue for 4 and $6 \mathrm{~h}$ gave good contrast between eggsacs and root tissues. Occasionally, root tips were faintly stained but this did not affect the contrast between eggsac and root tissue.

\section{Reaction of pigeonpea genotypes}

Pigeonpea genotypes ICP 28, 1207, 2627, 7182, 7191, 7194, 7222, 7739, 8520, 11920, 11981 , $12974,13326,13525$ and 14281 were rated 9, ICP 2624,7647 and 7862 were rated 8 and ICP 7119 and 8518 were rated 7 .

\section{Discussion}

Pigeonpea genotypes can be evaluated for resistance to $R$. reniformis by counts of eggsacs on infected roots 30 to 45 days after seedling emergence but examination of 30 day old seedlings is faster and more precise due to the smaller root mass. The life cycle of $R$. reniformis is short and eggsacs appear on the roots of 15 day old seedlings; however, assessment after 15 days is not reliable with large variations in eggsac counts and many females without eggsacs. Infestation levels of 6 and fewer $R$. reniformis per $\mathrm{cm}^{3}$ soil result in variable and low ratings. The use of trypan blue for staining eggsacs is very useful because it does not involve heating the roots in the stain. In addition, viability of eggs is not adversely affected by the stain. This method is faster than screening procedures wherein roots are screened with the aid of a stereoscopic microscope (Birchfield, 1963; Birchfield \& Brister, 1969; Birchfield, Williams, Hartwig \& Brister, 1971 ; Chavda et al., 1988; Nayak, Routray \& Das, 1987; Patel, Chavda \& Patel, 1989; Patel et al., 1988).

Soil infestation levels of $R$. reniformis, age of the seedlings at the time of screening and observations to be recorded for resistance evaluations (counts of females eggsacs or eggs) have not been standardised. Soil infestation levels between 0.2 and $6.0 R$. reniformis per $\mathrm{g}$ or $\mathrm{cm}^{3}$ of soil have been used and roots screened for $R$. reniformis female or eggsac or egg numbers $12-25$ days after nematode inoculations (Chavda et al., 1988; Patel et al., 1987; Thakar \& Yadav, 1987). We suggest that sowing genotypes in soil infested with 15 or more individuals of $R$. reniformis per $\mathrm{cm}^{3}$ soil and evaluation of the root systems of 30 day old seedlings grown at 25 $30{ }^{\circ} \mathrm{C}$ after staining in $0.25 \%$ trypan blue for 3 to $5 \mathrm{~min}$ will be helpful in evaluating pigeonpea for resistance to this nematode. 


\section{Acknowledgements}

We acknowledge Drs D. McDonald, D. H. Smith, Legumes Pathology, ICRISAT, and P. A. Roberts and Charles Omwega, Department of Nematology, University of California, Riverside, USA for critically reading the manuscript.

\section{References}

Birchfield, W. (1963). Susceptibility of cotton and relatives to reniform nematode in Louisiana. Plant Disease Reporter 47, 990-992.

Birchfield, W. \& Brister, L. R. (1969). Reaction of soybean varieties to the reniform nematode, Rotylenchulus reniformis. Plant Disease Reporter 53, 999-1000.

Birchfield, W., Williams, C., Hartwig, E. E. \& Brister, L. R. (1971). Reniform nematode resistance in soybeans. Plant Disease Reporter 55, 1043-1045.

Chavda, J. C., Patel, B. A. \& Patel, D. J. (1988). Screening of pigeonpea lines to Rotylenchulus reniformis. International Nematology Network Newsletter 15, 28-29.

Nayak, D. K., Routray, B. N. \& Das, S. N. (1987). Relative susceptibility of some horsegram cultivars against reniform nematodes Rotylenchulus reniformis. International Nematology Network Newsletter 4, 19-20.

Patel, B. A., Chavda, J. C. \& Patel, D. J. (1989). Screening of certain greengram lines against reniform nematode, Rotylenchulus reniformis. International Nematology Network Newsletter 6, 25-26.

Patel, B. A., Chavda, J. C., Patel, S. T. \& Patel, D. J. (1987). Reaction of some pigeonpea lines to reniform nematode (Rotylenchulus reniformis). International Pigeonpea Newsletter 6, 57-58.

Sharma, S. B. \& McDonald, D. (1990). Global status of nematode problems of groundnut, pigeonpea, chickpea, sorghum and pearlmillet, and suggestions for future work. Crop Protection 9, 453-458.

Sharma, S. B. \& Nene, Y. L. (1988). Effect of Heterodera cajani, Rotylenchulus reniformis and Hoplolaimus seinhorsti on pigeonpea biomass. Indian Journal of Nematology 18, 273-278.

Thakar, N. A. \& Yadav, B. S. (1987). Evaluation of pigeonpea varieties/lines for resistance against the reniform nematode. Indian Journal of Nematology 17, 132-133.

(Received 6 April 1991) 